\section{National HIV Testing Day - June 27, 2016}

National HIV Testing Day (http://www.cdc.gov/ features/HIVtesting), June 27, highlights the importance of testing in detecting, treating, and preventing human immunodeficiency virus (HIV) infection. Awareness of HIV infection through HIV testing is the first step to prevention, health care, and social services that improve quality of life and length of survival (1). CDC's National HIV Behavioral Surveillance (NHBS) monitors behaviors among populations at risk for acquiring or transmitting HIV infection. In 2012, NHBS data indicated that $9 \%$ of persons who inject drugs tested positive for HIV, and among those persons, $36 \%$ were unaware of their infection before testing (2). In 2013, $2 \%$ of heterosexuals at increased risk for HIV infection tested positive for HIV, and among those, $44 \%$ were unaware of their infection before testing (3). In 2014, among $22 \%$ of men who have sex with men who tested HIV-positive, $25 \%$ were unaware of their infection before testing (4).

Basic HIV testing information for consumers (http://www.cdc.gov/hiv/basics/testing.html) and health professionals (http://www.cdc.gov/hiv/testing), and CDC guidelines for HIV testing of serum (http://www.cdc.gov/ hiv/testing/laboratorytests.html) are available online.

\section{References}

1. Bradley H, Hall HI, Wolitski RJ, et al. Vital signs: HIV diagnosis, care, and treatment among persons living with HIV - United States, 2011. MMWR Morb Mortal Wkly Rep 2014;63:1113-7.

2. CDC. HIV infection, risk, prevention, and testing behaviors among persons who inject drugs. Atlanta, GA: US Department of Health and Human Services, CDC; 2015. http://www.cdc.gov/hiv/pdf/ library/reports/surveillance/cdc-hiv-HSSR_NHBS_PWID_2012.pdf

3. CDC. HIV infection, risk, prevention, and testing behaviors among heterosexuals at increased risk of HIV infection. Atlanta, GA: US Department of Health and Human Services, CDC; 2013. http:// www.cdc.gov/hiv/pdf/library/reports/surveillance/cdc-hiv-hssr_ nhbs_het_2013.pdf

4. CDC. HIV infection risk, prevention, and testing behaviors among men who have sex with men. Atlanta, GA: US Department of Health and Human Services, CDC; 2014. http://www.cdc.gov/hiv/pdf/ library/reports/surveillance/cdc-hiv-hssr-nhbs-msm-2014.pdf

\section{Evaluation of the Impact of National HIV Testing Day - United States, 2011-2014}

Shirley Lee Lecher, $\mathrm{MD}^{1}$; NaTasha Hollis, $\mathrm{PhD}^{1}$; Christopher Lehmann, $\mathrm{MD}^{1}$; Karen W. Hoover, $\mathrm{MD}^{1}$; Avatar Jones ${ }^{1}$; Lisa Belcher, $\mathrm{PhD}^{1}$

Human immunodeficiency virus (HIV) testing is the first step in the continuum of HIV prevention, care, and treatment services, without which, gaps in HIV diagnosis cannot be addressed. National HIV testing campaigns are useful for promoting HIV testing among large numbers of persons. However, the impact of such campaigns on identification of new HIV-positive diagnoses is unclear. To assess whether National HIV Testing Day (NHTD, June 27) was effective in identifying new HIV-positive diagnoses, National HIV Prevention Program Monitoring and Evaluation (NHM\&E) data for CDC-funded testing events conducted during 20112014 were analyzed. The number of HIV testing events and new HIV-positive diagnoses during June of each year were compared with those in other months by demographics and target populations. The number of HIV testing events and

\section{INSIDE}

619 Health Care Use and HIV Testing of Males Aged 15-39 Years in Physicians' Offices - United States, 2009-2012

623 State and Local Comprehensive Smoke-Free Laws for Worksites, Restaurants, and Bars - United States, 2015

627 Screening of Blood Donations for Zika Virus Infection - Puerto Rico, April 3-June 11, 2016

629 Zika Virus Surveillance and Preparedness New York City, 2015-2016

636 Announcement

637 QuickStats

Continuing Education examination available at http://www.cdc.gov/mmwr/cme/conted_info.html\#weekly.

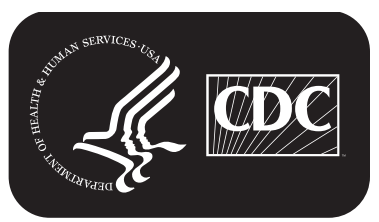

